\title{
PENGOBATAN TRADISIONAL DALAM NASKAH - NASKAH MINANGKABAU: Inventarisasi Naskah, Teks dan Analisis Etnomedisin
}

\author{
Danang Susena \\ Pramono \\ Herry Nur Hidayat
}

\begin{abstract}
Abstrak
Naskah-naskah Minangkabau memiliki beragam teks, seperti teks keislaman, sejarah, sastra, adat dan pengobatan tradisional. Jika teks keislaman, sejarah, sastra dan adat sudah banyak dikaji, maka untuk teks pengobatan tradisional masih minim kajian terhadapnya. Dengan menggunakan pendekatan filologi dan etnomedisin, penelitian ini dilakukan untuk mengisi kekosongan kajian terhadap teksteks pengobatan tradisional yang terkandung dalam naskah-naskah Minangkabau. Teknik pengumpulan data dilakukan melalui inventarisasi naskah, transliterasi dan penerjemahan, kritik teks dan wawancara. Data yang terkumpul akan dianalisis dengan menggunakan analisis data kualitatif dilakukan dengan tiga langkah sistematis secara jalinberjalin, yakni reduksi data, penyajian data, dan penarikan simpulan. Dari penelitian ini diketahui bahwa melalui teks pengobatan tradisional terdapat informasi tentang pengobatan tradisional Minangkabau yang berkaitan dengan ramuan obat dan cara pengobatan tradisional. Di samping itu, melalui konteksnya, dapat dimaknai tentang konsep sakit dan upaya penyembuhannya dalam kosmologi masyarakat Minangkabau.
\end{abstract}

Katakunci:pengobatantradisional,naskah,Minangkabau, teksdametnomedisin.

\section{Abstract}

Minangkabau old manuscripts have various texts such as Islamic text, history, literature, local custom and tradition, and traditional healing and medicines. The texts on Islam, literature, and local custom have been rapidly studied, but the texts on traditional healing and medicines recieved very little interests and studies. Utilizing the philological approach and etnomedicine, this research was conducted to cover the lack of studies on the texts of traditional healing and medicines which are found in Minangkabau old manuscripts. The data were collected through listing 
the manuscripts, transliteration and translation, textual criticism and interview. The collected data were analized by qualitative data analysis which was done through three pararel-systimaticalsteps; datareductions, datapresentation and drawing the conclusion. From this research, it is found that the texts of traditional healing and medicines convey the information on Minangkabau traditional healing and medicine including the formula of the medicines and the method of traditional healing. Besides that, it helps to contextually comprehend the concept of illness and the method of healing in the cosmology of Minangkabau society.

Keywords: traditional healing and medicines, manuscripts, Minangkabau, text and etnomedicine.

\section{Pendahuluan}

Minangkabau memiliki khazanah warisan budaya tertulis dalam bentuk naskah (manuskrip) yang jumlahnya ribuan. Sebagian naskah-naskah tersebut tersimpan di berbagai perpustakaan, baik di dalam negeri maupun di luar negeri. Di dalam negeri, naskah-naskah Minangkabau tersimpan di Perpustakaan Nasional Republik Indonesia (78 naskah), Perpustakaan Museum Adytiawarman Sumatera Barat (60 naskah), Badan Perpsutakaan dan Kearsipan Sumatera Barat dan di Labor Filologi Fakultas Ilmu Budaya, Universitas Andalas, Padang (20 naskah). Di luar negeri, berdasarkan katalogus naskah, Zuriati (2003:1) menghitung ada 383 naskah Minangkabau yang tersebar di beberapa perpustakaan, seperti di Belanda (261 naskah), Inggris (102 naskah), Jerman Barat (19 naskah) dan Malaysia (1 naskah).

Akan tetapi, sebenarnya naskah Minangkabau dengan jumlah yang jauh lebih besar masih tersebar di tangan masyarakatnya di Sumatera Barat. Hal ini dibuktikan dengan berbagai hasil inventarisasi yang dilakukan oleh para peneliti. Berbagai inventarisasi naskah-naskah Minangkabau koleksi masyarakat di Sumatera Barat itu seperti yang dilakukan oleh Yusuf (2006), Akhimuddin (2007), Zuriati, dkk. (2008), Irina Katkova \& Pramono (2009) M. Yusuf, Andriana Yohan dan Fitria Dewi (2008), Yusri Akhimuddin, Andriana Yohan dan Fitria Dewi (2009), Pramono (2009) dan Irina Katkova \& Pramono (2011). Selain itu, hingga saat ini, kegiatan inventarisasi naskah-naskah Minangkabau koleksi masyarakat masih dilakukan oleh Kelompok Kajian Poetika, Fakultas Ilmu Budaya, Universitas Andalas. Dari berbagai inventarisasi itu telah terdata seribuan naskah Minangkabau yang dikoleksi masyarakat di Sumatera Barat.

Dari jenis teksnya, kebanyakan naskah yang terdata dari berbagai penelitian di atas, memuat teks keislaman, kemudian berturut-turut dengan jumlah yang lebih sedikit naskah-naskah jenis surat, adat dan undang-undang Minangkabau, kesusastraan, perobatan tradisional, mantra dan azimat. Setidaknya ada dua hal yang menyebabkan dominannya teks-teks keislaman dalam naskah-naskah Minangkabau. Pertama, hampir seluruh naskah-naskah kuno Minangkabau disalin dan ditulis di surau-surau tarekat yang tersebar di Sumatera Barat. dengan kata lain, surau-surau tersebut merupakan scriptorium naskah-naskah kuno Minangkabau. Kedua, sangat dimungkinkan karena dominasi Islam di Minangkabau cukup 
signifikan. Para syaikh atau ulama tidak hanya berperan dalam bidang keagamaan saja, tetapi juga berperan dalam masalah sosial.

Berbeda dengan naskah-naskah Nusantara lainnya, sampai saat ini belum ditemukan teks pengobatan tradisional utuh dalam satu naskah Minangkabau. Biasanya, teks pengobatan tradisional tidak terpisahkan dengan teks azimat dan mantra. Hal ini karena kedua teks terakhir ini kebanyakan juga digunakan untuk pengobatan. Mantra atau disebut dengan manto dalam bahasa Minangkabau misalnya, sampai hari ini masih dikenal luas di tengah masyarakatnya. Kata manto mengacu pada dua pengertian, yang pertama kata manto mengacu pada bahan ramuan yang digunakan untuk mengobati seseorang, seperti dedaunan, air, akarakaran dan lain-lain. Pengertian kedua, kata manto mengacu pada sesuatu yang dibacakan oleh seseorang (dukun) (Usman, 2002: 394).

Di samping itu, teks pengobatan tradisional itu biasanya juga terdapat dalam satu naskah yang mengandung teks-teks yang lain, seperti teks keislaman, sejarah dan adat. Dengan menggunakan naskah-naskah Minangkabau yang terdapat di Sumatera Barat, baik koleksi perpustakaan dan museum, maupun koleksi masyarakat secara pribadi, sebagai naskah penelitian, dalam artikel ini selanjutnya akan dideskripsikan naskah-naskah Minangkabau yang mengandung teks pengobatan tradisional, termasuk bahasa yang digunakan dalam penulisannya. Di samping itu, juga akan dideskripsikan berbagai macam pengobatan tradisional yang terkandung dalam naskah-naskah tersebut. Penting kemudian juga akan dijelaskan konteks kebudayaan dari teks pengobatan tradisional tersebut dalam perspektif etnomedisin.

Penelitian ini menggunakan metode penelitian kualitatif dengan pendekatan filologi dan etnomedisin. Untuk mencapai tujuan penelitian, diadakan serangkaian penelitian yang terdiri dari penelitian kepustakaan dan penelitian lapangan. Secara teknis, dalam upaya pengumpulan data, dalam penelitian ini akan diadakan serangkaian teknik penelitian, yakni inventarisasi naskah, transliterasi dan penerjemahan, kritik teks dan wawancara. Inventarisasi naskah bertujuan untuk mendaftarkan semua naskah yang akan diteliti - selanjutnya akan disebut "naskah penelitian" - di berbagai tempat penyimpanan naskah-naskah Minangkabau yang mengandung teks pengobatan tradisional, seperti di Museum Adytiawarman Provinsi Sumatera Barat, Badan Perpustakaan dan Kearsipan Sumatera Barat serta pada koleksi pribadi masyarakat. Pada tahap ini naskah penelitian juga akan didata melalui katalogus-katalogus Minangkabau yang telah ada. Setelah itu baru pada koleksi-koleksi masyarakat yang belum terdata keberadaannya.

Setelah naskah penelitian telah terinventarisir, langkah selanjutnya adalah melakukan transliterasi dan terjemahan. Teknik penelitian berikutnya adalah kritik teks, yakni salah satu tahap terpenting dari sebuah penelitian filologi. Kata "kritik" itu sendiri bisa berarti 'sikap menghakimi dalam menghadapi sesuatu' sehingga dapat berarti 'menempatkan sesuatu sewajarnya' atau 'memberikan evaluasi'. Jadi, kritik teks berarti 'menempatkan teks pada tempat yang sewajarnya, memberikan evaluasi terhadap teks, serta meneliti atau mengkaji lembaran naskah'. Jika sudah 
melewati tahapan ini berarti akan tersedia edisi teks; teks dapat dimengerti dan dipahami oleh khalayak yang lebih luas. Untuk melihat konteks budaya dari edisi teks tersebut akan dilakukan wawancara mendalam dengan beberapa narasumber yang dianggap memiliki pengetahuan mendalam terkait pengobatan tradisional Minangkabau.

Data yang terkumpul dianalisis dengan menggunakan analisis data kualitatif dilakukan dengan tiga langkah sistematis secara jalin-berjalin, yakni sebelum, selama, dan sesudah pengumpulan data, sesuai dengan anjuran Miles (1992:19). Ketiga langkah sistematis tersebut adalah reduksi data, penyajian data, dan penarikan simpulan.

\section{Deskripsi Naskah}

Seperti telah disebutkan di atas, bahwa teks pengobatan tradisional Minangkabau tidak ditemukan utuh dalam satu naskah. Pada tahap awal, untuk mengetahui naskah-naskah Minangkabau yang memuat teks pengobatan tradisional, dilakukan inventarisasi naskah melalui penelusuran katalogus dan daftar naskah yang telah disusun oleh beberapa peneliti seperti berikut ini.

1. M. Yusuf [Peny.] (2006), Katalogus Manuskrip dan Skriptorium Minangkabau yang diterbitkan oleh Centre for Documentation and Area-Transcultural Studies, Tokyo University of Foreign Studies di Tokyo.

2. M. Yusuf, Andriana Yohan \& Fitria Dewi (2008), laporan penelitian Balai Bahasa Padang dengan judul "Penelusuran Naskah di Kota Sawahlunto dan Kabupaten Sijunjung".

3. Zuriati (2008), laporan penelitian untuk Programme Endangered, British Library, London, dengan judul "The Digitisation of Minangkabau's Manuscript Collections in Suraus".

4. Yusri Akhimuddin, Andriana Yohan \& Fitria Dewi (2009), laporan penelitian Balai Bahasa Padang dengan judul "Penelusuran dan Deskripsi Naskahnaskah Koleksi Pribadi di Kabupaten Dharmasraya”.

5. Yusri Akhimuddin (2007), laporan penelitian mandiri denganjudul “Pemetaan Naskah-naskah Keagamaan di Padang Pariaman".

6. Pramono (2009), laporan penelitian Hibah Strategis Nasional dengn judul "Inventarisasi, Katalogisasi dan Digitalisasi Naskah-naskah Kuno Melayu dan Upaya Penyelamatannya di Sumatera Barat, Riau dan Kepulauan Riau".

7. Irina Katkova \& Pramono (2009), laporan penelitian untuk Programme Endangered, British Library, London, dengan judul “Endangered Manuscripts of Western Sumatra: Collections of Sufi Brotherhoods".

8. Irina Katkova \& Pramono (2011), laporan penelitian untuk Programme Endangered, British Library, London, dengan judul "Endangered manuscripts of Western Sumatra and the province of Jambi. Collections of Sufi brotherhoods".

9. Tim Peneliti Badan Perpustakaan dan Kearsipan Sumatera Barat (BPKSB) (2011), laporan kegiatan “Alih Media Naskah Kuno Wilayah Kabupaten 
Dharmasraya".

10. Yumi Sugahara dkk., (2011), laporan tahun I penelitian kerja sama penyelamatan naskah-naskah di Sumatera Barat sampai 2014 dengan Tokyo University and Foreign Studies (TUFS) supported by Japanese Society for the Promotion of Science (JSPS) KAKENHI (Grants-in-Aid for Scientific Research), Grant Number 23402006, dengan judul “Inventarisasi, Katalogisasi dan Digitalisasi Naskah-naskah Koleksi Masyarakat di Sijunjung."

Selain mendeskripsikan naskah dari berbagai koleksi naskah yang tersebar di Sumatera Barat, sebagian penelitian di atas juga membuat digital naskah. Dari inventarisasi naskah yang dilakukan, ditemukan 27 naskah Minangkabau yang di dalamnya terkandung teks pengobatan tradisional. Adapun daftar naskah-naskah tersebut akan ditampilkan pada tabel 1.

Tabel 1. Persebaran naskah-naskah Minangkabau yang mengandung teks pengobatan tradisional

\begin{tabular}{|c|c|c|c|}
\hline $\begin{array}{c}\text { Katalogus \& } \\
\text { Daftar Naskah }\end{array}$ & Nomor Naskah & Judul Naskah & $\begin{array}{l}\text { Kode Naskah } \\
\text { Penelitian }\end{array}$ \\
\hline \multirow{2}{*}{$\begin{array}{l}\text { M. Yusuf [peny.] } \\
(2006)\end{array}$} & MM.08.Matur.08 & Kitab Perobatan? & $\left(\mathrm{A}_{1}\right)$ \\
\hline & MM.08.Museum.32 & Kitab Azimat & $\left(A_{2}\right)$ \\
\hline \multirow{11}{*}{$\begin{array}{l}\text { Zuriati, dkk. } \\
\quad(2008)\end{array}$} & EAP144_DMMCS_P_03 & Azimat & $\left(\mathrm{B}_{1}\right)$ \\
\hline & EAP144_DMMCS_P_17 & [Tarekat, Pengobatan dll.] & $\left(\mathrm{B}_{2}\right)$ \\
\hline & EAP144_DMMCS_P_18 & [Fiqih, Mantra dll.] & $\left(\mathrm{B}_{3}\right)$ \\
\hline & EAP144_DMMCS_P_20 & [Nazam, Mantra dll.] & $\left(\mathrm{B}_{4}\right)$ \\
\hline & EAP144_DMMCS_P_27 & [Tarekat, Mantra dll.] & $\left(\mathrm{B}_{5}\right)$ \\
\hline & EAP144_DMMCS_P_28 & [Doa, Mantra dll.] & $\left(\mathrm{B}_{6}\right)$ \\
\hline & EAP144_DMMCS_P_31 & [Tasawuf, Mantra dll.] & $\left(\mathrm{B}_{7}\right)$ \\
\hline & EAP144_DMMCS_P_33 & [Tasawuf, Mantra dll.] & $\left(\mathrm{B}_{8}\right)$ \\
\hline & EAP144_DMMCS_MALS_29 & $\begin{array}{l}\text { [Asraru al-Shalat, Mantra } \\
\text { dll.] }\end{array}$ & $\left(\mathrm{C}_{1}\right)$ \\
\hline & EAP144_DMMCS_MALS_31 & [Fiqih, Azimat dll.] & $\left(\mathrm{C}_{2}\right)$ \\
\hline & EAP144_DMMCS_MNPR_69 & [Tasawuf, Mantra dll.] & $\left(\mathrm{C}_{3}\right)$ \\
\hline Pramono (2009) & $\begin{array}{l}\mathrm{P} \quad \mathrm{H} \quad \mathrm{S} \text { N } \quad \text { I K D N } \\
\text { DIPAUNAND_2009_NKM_SB_- } \\
\text { KP_Z_Tasauf dll. }\end{array}$ & [Tasawuf, Pengobatan dll.] & (D) \\
\hline BPKSB (2011) & BPKSB_AMN_2009_D_07 & [Fiqih, Pengobatan dll.] & $(\mathrm{E})$ \\
\hline \multirow{2}{*}{$\begin{array}{l}\text { Irina Katkova \& } \\
\text { Pramono (2011) }\end{array}$} & EAP352_EMWSPJCSB_SS_5 & [Tasawuf, Pengobatan dll.] & $\left(\mathrm{F}_{1}\right)$ \\
\hline & EAP352_EMWSPJCSB_SS_6 & [Fiqih, Pengobatan dll.] & $\left(\mathrm{F}_{2}\right)$ \\
\hline
\end{tabular}




\begin{tabular}{|l|lll}
\hline \multirow{2}{*}{$\begin{array}{l}\text { Yumi Sugahara } \\
\text { dkk. (2011) }\end{array}$} & CL_SJ_2011_19 & [Kumpulan Doa dan Zikir] & $\left(\mathrm{G}_{1}\right)$ \\
\cline { 2 - 4 } & CL_SJJ_2011_26 & & $\left(\mathrm{G}_{2}\right)$ \\
\cline { 2 - 4 } & CL_SJ_2011_38 & [Fiqih, Mujarobat dll.] & $\left(\mathrm{G}_{3}\right)$ \\
\cline { 2 - 4 } & CL_SJ_2011_42 & [Tasawuf, Mujarobat dll.] & $\left(\mathrm{G}_{4}\right)$ \\
\cline { 2 - 4 } & CL_SJ_2011_45 & {$[$ [Doa, Azimat dll.] } & $\left(\mathrm{G}_{5}\right)$ \\
\cline { 2 - 4 } & CL_SJ_2011_60 & [Fiqih, Rajah dll.] & $\left(\mathrm{G}_{6}\right)$ \\
\cline { 2 - 4 } & CL_SJJ_2011_68 & [Tasawuf, Mantra dll.] & $\left(\mathrm{G}_{7}\right)$ \\
\cline { 2 - 4 } & CL_SJ_2011_76 & [Kumpulan Doa, Mantra & $\left(\mathrm{G}_{8}\right)$ \\
\cline { 2 - 4 } & CL_SJJ_2011_99 & dill.] & $\left(\mathrm{G}_{9}\right)$ \\
\hline
\end{tabular}

Setelah dilakukan penelusuran dan pembacaan langsung di tempat koleksi naskah, yakni di Matur, Agam, ternyata naskah $\left(\mathrm{A}_{1}\right)$ yang diberi judul "Kitab Perobatan" hanya sedikit berisi teks pengobatan. Di dalam naskah tersebut lebih banyak berisi teks tarekat Naqsabandiyah. Naskah ini beralas kertas bergaris dengan ukuran $8 \times 13,8 \mathrm{~cm}$ dan tebalnya 96 halaman. Tulisan menggunakan aksara Jawi dan Arab dan setiap halaman rata-rata berisi 10 baris tulisan. Kondisi fisik naskanya masih bagus dan tulisannya masih dapat dibaca dengan jelas. Menurut kolofonnya, naskah ini "dibeli dari Taeh Baruh, Kampung Piliang 1321 Hijriah tanggal 8". Naskah ini merupakan koleksi M. Arif Katik Sutan Dirajo (72 tahun), yang beralamat di Jorong Ampek Surau, Nagari Matua Hilie, Kecamatan Matur, Kabupaten Agam (Yusuf [peny.], 2006 : 74).

Naskah $\left(\mathrm{A}_{2}\right)$ merupakan koleksi Museum Adytiawarman, Sumatera Barat. Salam halnya dengan naskah $\left(\mathrm{A}_{1}\right)$, naskah yang diberi judul "Kitab azimat" ini ternyata tidak seluruhnya berisi tentang azimat. Di dalam naskahnya, selain teks pengobatan tradisional yang dilengkapi dengan berbagai macam azimat juga berisi teks tasawuf dan fikih. Alas naskahnya kertas Eropa dengan ukuran 12,6 x 5,2 cm dan tebal naskahnya 182 halaman. Aksara yang digunakan adalah aksara Jawi dan Arab dengan rata-rata setiap halaman terdiri dari 14 baris. Kondisi fisik naskahnya sudah mulai rusak, tetapi masih banyak tulisan yang dapat dibaca dengan jelas (Yusuf [peny.], 2006 : 134).

Teks pengobatan tradisional banyak ditemukan pada naskah-naskah koleksi Surau Parak Laweh, Pariangan, Kabupaten Tanah Datar. Dari 33 naskah koleksi surau tersebut yang telah dideskripsikan dan didigitalkan oleh Zuriati (2008), ditemukan delapan naskah di antaranya mengandung teks pengobatan tradisional. Naskah $\left(B_{1}\right)$ berisi teks pengobatan tradisional berupa azimat yang digunakan untuk meningkatkan kesuburan perempuan, sebagai perisai untuk melindungi dari kejahatan ilmu hitam, sebagai penghilang rasa takut dan untuk menangkal tikus di sawah. Di dalamnya juga terdapat uraian tentang tarekat Syattariyah. Alas naskah ini adalah kertas Eropa dengan ukuran 20 x $15 \mathrm{~cm}$ dan terdiri dari 16-19 baris setiap halaman serta tebal naskahnya hanya 10 halaman. Teks ditulis dengan aksara Arab 
dan Jawi dengan warna tinta hitam dan merah. Kondisi naskah masih bagus dan tulisannya masih dapat dibaca dengan jelas (Zuriati, $2008: 4$ ).

Naskah $\left(B_{2}\right)$ hanya berisi sedikit teks pengobatan tradisional dan lebih banyak berisi hukum Minangkabau, adab murid dalam tarekat, masalah logika dan penalaran dan hukum adat. Naskah ini beralas kertas Eropa dengan ukuran fisik naskahnya $16 \times 9,5 \mathrm{~cm}$ dan tebal naskahnya 58 halaman. Tulisan di dalam naskah menggunakan aksara Jawi dan Arab yang masing-masing halaman berisi 11-16 baris . Kondisi naskahnya kurang bagus, tetapi tulisannya masih dapat dibaca (Zuriati, 2008 : 19).

Hampir sama dengan naskah di atas, naskah $\left(B_{3}\right)$ juga berisi sedikit teks pengobatan tardisional. Teks pengobatan tradisional dilengkapi dengan azimat dan mantra, seperti mantra untuk menetralisir racun dan pelindung diri dari pengaruh jahat. Selain itu, di dalam naskah ini juga berisi teks fiqih. Alas naskanya kertas bergaris dengan ukuran naskah 16,5 x 10,4 cm dan tebal naskahnya hanya 24 halaman. Tulisan dalam naskah menggunakan aksara Jawi dan Arab dengan masing-masing halaman terdiri 10-19 baris tulisan. Kondisi naskahnya kurang bagus, tetapi tulisannya masih dapat dibaca (Zuriati, 2008 : 22).

Naskah $\left(\mathrm{B}_{4}\right)$ berisi tiga teks, yakni teks tata bahasa Arab, nazam Sunur dan mantra pekasih dan pengobatan. Alas naskahnya kertas Eropa dengan ukran naskah 16,5 x 10,4 cm dan tebal naskahnya 46 halaman. Tulisannya menggunakan aksara Jawi dan Arab dengan masing-masing halaman rata-rata terdiri dari 22 baris tulisan. Kondisi fisik naskahnya kurang bagus, tetapi tulisannya masih dapat dibaca. Naskah $\left(\mathrm{B}_{5}\right)$ jauh lebih tipis dibandingkan dengan naskah $\left(\mathrm{B}_{4}\right)$, yakni hanya 18 halaman. Naskah ini terdiri dari dua teks, teks tarekat dan mantra (termasuk mantra pengobatan). Ukuran fisik naskahnya 17 x 10,3 cm dan masing-masing halaman terdiri rata-rata 15 baris tulisan. Tulisan menggunakan aksara Jawi dan Arab. Adapun kondisi fisik naskahnya juga kurang bagus, tetapi tulisannya masih dapat dibaca (Zuriati, 2008 : 29-30).

Naskah $\left(\mathrm{B}_{6}\right)$ berisi dua teks, yakni teks doa dan mantra (termasuk juga mantra pengobatan). Di dalamnya juga terdapat beberapa ilustrasi berupa gambar tubuh manusia, ular, kelabang dan beberapa motif hiasan. Alas naskahnya kertas Eropa dengan ukuran naskah 16.8 x $10.3 \mathrm{~cm}$ dan tebal naskahnya 56 halaman. Tulisan menggunakan aksara Jawi dan Arab yang setiap halamannya terdiri 15-21 baris tulisan. Kondisi fisik naskah kurang bagus, tetapi tulisannya masih dapat dibaca (Zuriati, $2008: 33$ ).

Naskah $\left(B_{7}\right)$ sangat tipis, hanya 10 halaman yang berisi teks tentang tasawuf dan sedikit tentang teks mantra pengobatan tradisional. Alas naskahnya kertas Eropa dengan ukuran fisik naskah 17 x 10,5 cm. Tulisannya menggunakan Aksara Jawi dan Arab dan setiap halaman berisi 10-16 baris tulisan. Kondisi fisik naskah ini sangat rusak dan banyak tulisan yang tidak dapat dibaca lagi (Zuriati, 2008 : 35). Naskah $\left(\mathrm{B}_{8}\right)$ juga berisi teks tasawuf dan mantra, tetapi naskahnya lebih tebal, yakni 90 halaman. Alas naskahnya juga kertas Eropa dengan ukuran naskah 20 x $16 \mathrm{~cm}$. Tulisan menggunakan aksara Jawi dan Arab yang masing-masing halaman terdiri 
rata-rata 17 baris tulisan. Kondisi fisik naskah kurang bagus, tetapi masih banyak tulisannya yang masih dapat dibaca (Zuriati, $2008: 37$ ).

Selain koleksi naskah Surau Laweh di atas, peneliti juga menemukan tiga naskah koleksi surau-surau di Malalo, Kecamatan Batipuh Selatan, Kabupaten Tanah Datar, yang mengandung teks pengobatan tradisional. Dua naskah itu merupakan bagian dari 79 naskah koleksi surau-surau di Malalo yang juga telah dideskripsikan dan didigitalkan oleh Zuriati (2008). Pertama, naskah $\left(\mathrm{C}_{1}\right)$ yang diberi judul Asraru al-Shalat yang menjelaskan rahasia berdoa dan surat Al-Fatihah. Selain itu di dalamnya juga terdapat berbagai macam mantra, termasuk mantra pengobatan. Ukuran fisik naskahnya 22 x $14 \mathrm{~cm}$ dan tebal naskahnya 68 halaman. Tulisannya menggunakan aksara Jawi dan Arab dan masing-masing halaman terdiri dari 13-15 baris. Kondisi naskahnya rusak dan banyak tulisan yang tidak dapat dibaca lagi Zuriati, 2008 : 29).

Naskah $\left(C_{2}\right)$ berisi beberapa teks, di antaranya teks fiqih, azimat (termasuk azimat untuk pengobatan) dan cerita nabi. Alas naskahnya kertas Eropa dengan ukuran naskah $21 \times 16,8 \mathrm{~cm}$ dan tebal naskahnya 80 halaman. Tulisannya menggunakan aksara Jawi dan Arab yang masing-masing halaman terdiri dari 1319 baris tulisan. Kondisi naskahnya sudah rusak dan banyak tulisannya tidak dapat dibaca (Zuriati, 2008 : 34). Naskah $\left(\mathrm{C}_{3}\right)$ juga sudah rusak, tetapi banyak tyulisan yang masih dapat dibaca. Naskah ini cukup tebal, yakni terdiri dari 360 halaman. Ukuran fisik naskahnya 16,5 x 10,5 cm dan terdiri dari rata-rata 13 baris setiap halaman. Naskah yang ditulis dengan aksara Jawi dan Arab ini berisi beberapa teks, seperti teks tasawuf, takwil gempa dan mantra serta azimat pengobatan (Zuriati, 2008 : 73).

Selain naskah-naskah di atas, Pramono (2009) juga telah mendeskripsikan dan mendidigitalkan 80 naskah koleksi masyarakat yang tersebat di berbagai wilayah di Sumatera Barat. Akan tetapi, sayangnya, dari 80 naskah tersebut hanya satu naskah saja yang mengandung teks pengobatan tradisional, yakni salah satu naskah koleksi Surau Syekh Said Bonjol di Pasaman Timur: naskah (D). Naskah ini berisi teks tasawuf, ramuan pengobatan dan mantra. Alas naskahnya kertas Eropa dengan ukuran naskah $17 \times 21 \mathrm{~cm}$ dan tebal naskah 64 pages. Tulisannya menggunakan aksara Jawi dan Arab yang masing-masing halaman terdiri ratarata 15 baris tulisan. Kondisi ini cukup bagus dan tulisannya masih dapat dibaca (Pramono, 2009 : 87).

Satu naskah yang mengandung pengobatan tradisional juga ditemukan di antara enam koleksi Buya Rizal Abas di Pisang Rebus, Kabupaten Dharmasraya. Naskah ini, naskah (E), dideskripsikan dan didigitallkan oleh Tim Badan Perpsutakaan dan Kearsipan Sumatera Barat (2011). Naskah (E) terdiri dari beberapa teks, seperti teks tasawuf, fiqih dan ramuan serta mantra pengobatan. Ukuran naskahnya 16 × $22 \mathrm{~cm}$ dan tebalnya 70 halaman. Aksara yang digunakan Jawi dan Arab dengan masing-masiang halaman terdiri dari rata-rata 12 baris tulisan. Kondisi fisik naskahnya masih bagus dan tulisannya dapat dibaca dengan jelas (BPKSB, 2011:7).

Dalam Irina Katkova \& Pramono (2011) ditemukan dua naskah yang 
mengandung teks pengobatan tradisional dari lima naskah koleksi Surau Simpang, Matur, Kabupaten Agam. Dua naskah tersebut, naskah $\left(\mathrm{F}_{1}\right)$ dan $\left(\mathrm{F}_{2}\right)$, telah dideskripsikan dan didigitalkan. Dalam naskah $\left(\mathrm{F}_{1}\right)$ terkandung teks tasawuf dan pengobatan tradisional. Ukuran fisik naskahnya 11,5 x 16,5 cm dan tebal naskahnya 60 halaman. Alas naskah kertas Eropa dengan kondisi cukup bagus. Tulisan mengunakan aksara Jawi dan Arab dan masing-masing halaman terdiri rata-rata 15 baris tulisan. Adapun naskah $\left(\mathrm{F}_{2}\right)$ juga mengandung dua teks, yakni teks pengobatan dan fiqih. Akan tetapi, dalam naskah $\left(\mathrm{F}_{2}\right)$ lebih sedikit berisi teks pengobatan dibandingkan dengan naskah $\left(\mathrm{F}_{1}\right)$. Ukuran fisik naskah $\left(\mathrm{F}_{2}\right)$ lebih besar disbandingkan naskah $\left(\mathrm{F}_{1}\right)$, yakni 16 × $21 \mathrm{~cm}$ dengan tebal naskah 70 halaman. Tulisannya menggunakan aksara Jawi dan Arab dengan rata-rata setiap halaman terdiri dari 17 baris tulisan. Kondisi fisik naskahnya masih utuh dan tulisannya masih dapat dibaca.

Naskah yang mengandung teks pengobatan tradisional Minangkabau paling banyak ditemukan pada koleksi Surau Calau, di Sijunjung. Dari 100 naskah yang telah dideskripsikan dan didigitalkan oleh Yumi Sugahara (2011), diketahui ada 10 naskah yang di dalamnya terkandung teks pengobatan tradisional. Seperti tampak pada tabel 1, naskah-naskah penelitian yang berjumlah 10 naskah dengan kode naskah penelitian $\left(\mathrm{G}_{1}\right)$ sampai naskah $\left(\mathrm{G}_{10}\right)$.

Naskah $\left(G_{1}\right)$ terdiri dari beberapa teks, seperti teks kumpulan doa, mantra pengobatan dan zikir. Alas naskahnya kertas Eropa dengan ukuran naskah $17 \mathrm{x}$ 10,5 cm dan tebalnya 110 halaman. Tulisan menggunakan aksara Jawi dan Arab yang masing-masing halaman rata-rata terdiri 13 baris tulisan. Kondisi fisik naskah rusak dan banyak lembar naskah yang hilang, beberapa tulisan juga tidak dapat dibaca lagi.

Di dalam naskah $\left(G_{2}\right)$ terkandung banyak teks pengobatan tradisional dan hanya sedikit teks lain di dalamnya. Akan tetapi, sayangnya di dalam naskah ini teks pengobatan tradisional hanya terkait dengan mantra dan aziman. Adapun yang terkait dengan ramuan pengobatan tidak ditemukan. Ukuran fisik naskah ini 17 x $11 \mathrm{~cm}$ dan tebal nasknya 240 halaman. Tulisannya menggunakan aksara Jawi dan Arab. Kondisi fisik naskahnya masih bagus dan tulisannya dapat dibaca dengan jelas.

Naskah $\left(G_{3}\right)$ mengandung beberapa teks, seperti fiqih, tasawuf, doa dan pengobatan tradisional berupa azimat dan mantra. Ukuran fisik naskahnya 17 x $12 \mathrm{~cm}$ dengan alas kertas Eropo. Tebal naskah 170 halaman dan tulisannya menggunakan aksara Jawi dan Arab. Kondis fisik naskahnya cukup bagus, tetapi banyak lembaran kertas naskah yang hilang. Di dalamnya terdapat informasi tambahan dengan tulisan "ini surat Tuanku Di Bawah Manggih di Aur di Calau”.

Naskah $\left(\mathrm{G}_{4}\right)$ merupakan naskah yang tipis, yakni hanya 40 halaman. Di dalamnya juga hanya terdapat sedikit informasi pengobatan tradisional berupa azimat dan mantra, selebihnya berisi tentang doa. Ukuran naskahnya 17 x $10 \mathrm{~cm}$ dengan alas naskah berupa kertas Eropa. Tulisannya menggunakan aksara Jawi dan Arab yang masing-masing halaman terdiri rata-rata 11 baris tulisan. Kondisi fisik 
naskah ini cukup baik, tetapi beberapa lembarannya ada yang hilang. Pengobatan tradisional berupa azimat dan mantra juga terdapat pada naskah $\left(G_{5}\right)$, tetapi jumlah halamannya lebih banyak dibandingkan naskah $\left(\mathrm{G}_{4}\right)$, yakni setebal 240 halaman. Naskah $\left(G_{5}\right)$ beralas kertas Eropa dengan ukuran 17 × $10 \mathrm{~cm}$ dan tulisannya menggunakan aksara Jawi dan Arab. Kondisi fisik naskahnya cukup bagus dan tulisannya masih dapat dibaca.

Naskah $\left(\mathrm{G}_{6}\right)$ dengan tebal 140 halaman dengan tulisan Jawi dan Arab berisi teks tasawuf dan kumpulan mantra pengobatan tradisional. Ukuran naskahini $17 \times 10,5 \mathrm{~cm}$ yang di setiap halaman terdiri dari 12-15 baris tulisan. Kondisi fisik naskahnya rusak dan banyak tulisan yang tidak dapat dibaca lagi. Berbeda dengan naskah $\left(G_{6}\right)$ ini, naskah $\left(G_{7}\right)$ lebih tipis, yakni setebal 60 halaman. Di dalamnya terdapat teks azimat dan mantra pengobatan serta teks tasawuf. Ukuran naskahnya 15 x $10 \mathrm{~cm}$ dengan alas naskah kertas Eropa. Tulisannya menggunakan aksara Jawi dan Arab dan setiap halaman terdiri dari 16-20 baris tulisan. Kondisi fisik naskahnya masih utuh dan tulisan dapat terbaca dengan jelas.

Teks mantra dan ramuan pengobatan tradisional juga terdapat pada naskah $\left(G_{8}\right)$, yang di dalmnya juga terdapat teks fiqih. Alas naskahnya kertas Eropa dengan ukuran naskah 17 x $11 \mathrm{~cm}$ dengan ketebalan 120 halaman. Tulisannya menggunakan aksara Jawi dan Arab dan setiap halaman terdiri antara 15-17 baris tulisan. Kondsi fisik naskahnya masih bagus, tetapi beberapa lembaran kertas hilang. Teks pengobatan yang sama yang terkait mantra dan ramuan obat juga terdapat pada naskah pada naskah $\left(G_{9}\right)$. Akan tetapi naskah ini lebih tebal, 368 halaman, karena di dalam naskah ini terdapat banyak teks lain seperti iasawuf, fiqih dan sejarah. Kondisi naskahnya cukup rusak, banyak lembaran naskah berlubang dan banyak juga lembaran kertasnya yang hilang. Sama halnya dengan naskah $\left(G_{10}\right)$, juga naskah yang cukup tebal, 340 halaman, yang juga berisi teks mantra dan azimat pengobatan seperti terdapat pada naskah $\left(G_{8}\right)$ dan naskah $\left(G_{9}\right)$. Kondisinya juga sudah cukup rusak, banyak lembaran naskah yang hilang.

Dari pembacaan terhadap naskah-naskah yang mengandung teks pengobatan tradisional di atas, aspek kebahasaan memiliki kecenderungan yang berbeda dengan naskah-naskah Minangkabau pada umumnya. Naskah-naskah di atas semuanya ditulis dengan menggunakan bahasa Minangkabau. Kondisi ini berbeda dengan bahasa yang digunakan untuk teks lainnya dalam satu naskah yang juga terdapat teks pengobatan. Jika teks lain ditulis dengan menggunakan bahasa Melayu, maka untuk teks pengobatan (termasuk mantra) cenderung ditulis dengan menggunakan bahasa Minangkabau.

Dilihat dari segi kebahasaan tersebut tampak bahwa teks pengobatan tradisional Minangkabau masih memperlihatkan ketradisionalannya. Selain itu, mudah ditafsirkan kenapa teks mantra dan pengobatan tradisional di Minangkabau ditulis dengan menggunakan bahasa lokal (Minangkabau). Pada hakikatnya pengetahuan pengobatan tradisional adalah lisan bukan tertulis. Adapun ditulis dimaksudkan untuk mengingatnya, untuk diajarkan kepada orang lain. Oleh karena itu, penulisan pengobatan tradisional, khususnya dalam penulisan mantra 
haruslah mempertahankan bunyi bahasa aslinya, agar kekeuatan gaibnya tetap terjaga.

Menarik juga dikemukakan bahwa selain menggunakan bahasa Minangkabau, teks mantra pengobatan yang ditemukan dalam naskah-naskah di atas juga ditandai dengan pemakaian frase yang bercirikan Islam. Ciri keislaman tampat pada pemakaian kata sapaan atau frase, seperti bismillahirrahmanirrahim, Allah, malaikat, Nabi Muhammad, dan ayat-ayat Alquran. Hal ini menandakan bahwa dalam perkembangannya terjadi peleburan antara mantra dengan unsur-unsur Islam di Minangkabau.

\section{Teks Pengobatan Tradisional dalam Naskah-naskah Penelitian}

Sebagaimana disebutkan dalam bagian awal tulisan ini bahwa teks pengobatan tradisional biasanya terdapat di dalam naskah yang juga memuat teks-teks lain, seperti teks keislaman. Naskah-naskah tersebut ditulis di surausurau tarekat. Dengan demikian dapat ditafsirkan bahwa para buya, ulama dan atau syeikh di suatu surau tarekat selain memiliki pengetahuan keislaman juga mengerti tentang dunia pengobatan. Selain itu, teks pengobatan tradisional yang ditulis atau disalin sesungguhnya ada kaitannya dengan paham keagamaan. Oleh karena itu, wajar kiranya hingga hari ini masyarakat Minangkabau masih memiliki kepercayaan terhadap para syekh tertentu dan di surau tertentu untuk dimintai obat.

Dari transliterasi dan terjemahan yang dilakukan terhadap naskah-naskah Minangkabau yang mengandung teks pengobatan tradisional di atas, peneliti dapat mengelompokkan sistem pengobatan sebagai berikut: (1) pengobatan dengan ramuan saja; (2) pengobatan dengan mantra dan atau doa saja; (3) pengobatan dengan ramuan dan mantra; dan (4) pengobatan dengan menggunakan azimat. Masing-masing jenis pengobatan tersebut diuraiakan sebagai berikut.

\section{Pengobatan dengan ramuan saja}

Ada beberapa jenis obat yang selalu disebut dan digunakan sebagai ramuan untuk pengobatan yang ditemukan dalam naskah-naskah penelitian, yakni sitawa, sidingin, cikumpai, cikarau, bawang putih, bawang merah, kunyit, jahe dan limau kapas. Pengobatan yang menggunakan ramuan saja biasanya untuk mengobatti penyakit biasa, seperti sakit demam, sakit perut, sesak nafas, ambeyen dan lainlain. Sayangnya, untuk jenis pengobatan dengan menggunakan ramuan obat saja sangat sedikit ditemukan dalam naskah-naskah penelitian. Berikut ini merupakan sebagian hasil edisi teks (termasuk penerjemahan dan rekonstruksi teks) pengobatan yang hanya menggunakan ramuan saja yang ditemukan dalam naskah-naskah penelitian. 


\section{Panas dalam}

Daun kacang tujuh helai, daun lansano, tomat, telur ayam, gula batu, diremas, diaduk, diminum.

\section{Sakit perut}

Daun sicerek, jahe, remas dengan air hangat, minumkan. Ampasnya tempelkan di perut. Jika perut melilit-lilit rendam ampasnya dengan air hangat dan minumkan.

\section{Sakit perut}

Bawang putih dan bawang merah, tumbuk dan aduk dengan mintah tanah dan minyak goreng, urutkan pada perut dan betis.

\section{Perut melilit}

Akar salayo, akar putri malu, direndam dengan air panas menggelegak, setelah dingin minum.

\section{Perut mangareok}

Ramuannya daun kuciang jo supadan, ditumbuk, rendam dengan air hangat, diminum. Ampasnya ditempelkan ke perut.

\section{Ambeyen}

Akar putri malu, gula merah, direbus, diminum.

\section{Sesak nafas}

Asam sundai (jeruk purut yang besar), kelapa, kunyit, direbus, diminum.

\section{Sakit perut, kepala, sendi-sendi dan betis}

Obatnya daging kambing putih atau hitam atau belang atau ayam kurik, disembelih, direndang dengan minyak kelapa, dagingnya dimakan tanpa garam, minyak diusapkan ke tubuh.

\section{Pengobatan dengan mantra dan atau doa saja}

Teks pengobatan yang hanya dengan menggunakan mantra dan doa saja merupakan teks yang paling banyak yang terkandung dalam naskah-naskah penelitian. Fakta ini menjadi penting kemudian untuk dijelaskan konteks budaya dari teks tersebut, utamanya dengan perspektif etnomedisin. Dalam bagian ini akan dihadirkan saja sebagaian edisi teks yang ditemukan dalam naskahnaskah penelitian. Dalam penyajiannya sengaja dihadirkan teks asli (dalam bahasa Minangkabau) dan terjemahannya. Hal ini dimaksudkan untuk memberi penegasan bahwa penggunaan bahasa dalam penulisan mantra-mantra dalam naskah-naskah Minangkabau tidak menggunakan bahasa Melayu, tetapi dengan 
Bahasa Minangkabau. Berikut ini beberapa (sebagian) mantra pengobatan yang terkandung di dalam naskah-naskah penelitian.

\section{Mantra obat bisa (racun)}

Mantra ubek biso. Bismillahirrahmanirrahim, birah itam kaladi itam, tumbuah di ujuang bumi, manggigik si buyuang itam, bisonyo alah den turuni.

Mantra obat bisa. Bismillahirrahmanirrahim, kemumu hitam keladi hitam, tumbuh di ujung bumi, menggigit hewan yang berbisa, bisanya sudah aku turunkan.

\section{Mantra penawar upas atau racun}

Bismillahirrahmanirrahim. 'An kata Allah, Inna kata Muhammad, Maa sariiq kata Tuhan, laa ilaaha illallah engkau tiada melupakan aku, aku tiada melupakan engkau aku memandang engkau di dalam upas dan racun di dalam alam 'ian tsabitah nyatakan dia engkau di dalam alam 'ian. Kharajah mati, ali mati, aku tak mati ali tidak mati aku2 memakai garak raya asal mula jadi di dalam diri aku menggarap insan karena Muhammad menggarap Muhammad karena Allah laa ilaha illallah Muhammadarrasulullah.

\section{Mantra obat biriang}

Bismillahirrahmanirrahim. Wadi diair janiah, talatak ditanah jati, tubuahnyo janiah, asalnyo putiah, badiri sandirinyo. Wadi di tanah basa, talatak di dalam sarugo, turunlah aia zamzam kala kautsar dalam batang tubuah sianu, Takuciak, ta langkanglah angkau dalam diri, batang tubuah sianu, pahabiskan sakalian biso biriang, panarohok dibatang tubuah si anu, karano aku tahu di mulo asal angkau jadi, air maruyah asal engkau jadi, tahulah angkau dibatang tubuah sianu, tahu Allah, tahu Muhammad, tahu bagindo Rasulullah, nan tajam patapan nan biso tawa, Bismillahis Syafi, Bismillahil Ma'afi nan tajam panapan nan/ biso tawa nan hangek dingin, tajam do'aku dari pado kando Ya Rahman di Allah, rajo Sulaiman, luas di Allah, dihapuskan Allah, dihabiskan Allah, dihabiskan Muhammad, sekalian biriang, dihab rajah panah biso, dibatang tubuah sianu, berkat kebenaran do'a rajo sulaiman, tawa Allah, tawa Muhammad, tawa Bagiondo Rasulullah Kabul berakat Laa Ilaha Illallah".

Bismillahirrahmanirrahim. Wadi diair jernih, terletak di tanah jati, tubuhnya jernih, asalnya putih, berdiri sendirinya. Wadi di tanah besar, terletak di dalam surga, turunlah air zamzam kerika kautsar dalam batang tubuh sidia, Tergetar, terlangkahlah engkau dalam diri, batang tubuh sidia, menghabiskan sekalian bisa biriang, panarohok dibatang tubuh si dia, karena aku tahu di mula asal engkau jadi, air maruyan asal engkau jadi, tahulah engkau dibatang tubuh sidia, tahu Allah, tahu Muhammad, tahu baginda Rasulullah, nan tajam patapan nan bisa tawar, Bismillahis Syafi, Bismillahil Ma'afi yang tajam panapan yang/ bisa tawar yang hangat dingin, tajam doaku dari pada kanda Ya Rahman di Allah, raja Sulaiman, luas di Allah, dihapuskan Allah, dihabiskan Allah, dihabiskan Muhammad, sekalian biriang, 
dihab rajah panah bisa, dibatang tubuah sidia, berkat kebenaran doa raja Sulaiman, tawar Allah, tawar Muhammad, tawar Baginda Rasulullah Kabul berakat Laa Ilaha Illallah.

\section{Pengobatan dengan ramuan dan mantra}

Teks pengobatan jenis ini di dalam naskah-naskah penelitian dengan urutan mantra dahulu baru ramuan atau obatnya. Munculnya jenis pengobatan ini pun penting dijelaskan konteks budaya melalui pendekatan etnomedisin. Artinya, pengobatan jenis ini menganggap bahwa suatu penyakit tidak hanya disebabkan faktor fisikal saja, tetapi juga disebabkan karena pengaruh gaib. Berikut ini merupakan beberapa contoh jenis pengobatan yang menggunakan ramuan dan mantra yang ditemukan dari naskah-naskah penelitian.

\section{Sakit kepala}

Bismillahirrahmanirrahim. Inilah do'a (atau tawa) untuk sakik kapalo. Bismillahirrahmanirrahim tangkis daripado ilak, aku tahu diasal engkau, dari darah hitam diasal engaku, jadi tempat engkau di sulbi. Kembalilah engkau ke tempat engkau. Jangan engaku berbalik-balik, badu to kepada aku, kalau engkau berbalik-nbalik, berduto-duto kepada aku, engaku /5/ disumpahi Allah, disumpahi Muhammad, disumpahi Quran tigo puluah juz. Berkat laa ilaha illallah. Berkat Muhammad Rasulullah. Cara dan ramuannyo: ambil kelopak pisang, lidi, ditulis ini: Wala tahlaqu rusakmarhati yabiakhi ahaddi wanjagkana mingkum maithallaha iza man ruksah.

Bismillahirahmanirrahim. Inilah doa (mantra) untuk sakit kepala. Bismillahirahmanirrahim tangkis daripada elak, aku tahu asal engkau, jadi darah hitam diasal engkau, jadi tempat engkau di sulbi. Kembalilah engkau ke tempat engkau. Jangan engkau kembali lagi, berdusta kepada aku. Kalau engkau kembali lagi, berdusta kepada aku, engkau disumpah oleh Allah, disumpahi Muhammad, disumpahi Alquran tiga puluh juz. Berkat laa ilaha illallah. Berkat Muhammad Rasulullah. Cara dan ramuannya: ambil kelopak pisang, lidi, ditulis ini: Wala tahlaqu rusakmarhati yabiakhi ahaddi wanjagkana mingkum maithallaha iza man ruksah.

\section{Sakit perut}

Inilah tawa sakik perut. Hai kancang-kancang rayu si anu (nama orangnya) janganlah engkau merusakkan, maniayo pado si anu. Kalau engkau marusakkan, maniayo si anu (nama orang yang diobati), engkau disumpahi Allah, disumpahi Muhammad, disumpahi Quran tigo puluah juz. Berkat laa ilaha illa allah Muhammad Rasulullah. Ramuannyo: dasun dan bawang merah. Tokok, aduk dengan minyak tanah dan minyak manih, baruikkan pado paruik dan batihnyo.

Inilah mantra sakit perut. Hai kencang-kencang rayu si anu (nama orangnya) janganlah engkau merusak, menganiaya si anu. Kalau engkau merusak, menganiaya si anu (nama orang yang diobati), engkau disumpahi Allah, disumpahi Muhammad, 
disumpahi Alquran tiga puluh juz. Berkat la ilaha illallah Muhammad Rasulullah. Ramuannya: dasun dan bawang merah. Tokok, aduk dengan minyak tanah dan minyak goreng, diurutkan di perut dan betisnya.

Inilah penawar racun, Bismillahirrahmanirrahim, datang engkau dari upas jin, marah kembali engkau upas jin, marah aku tahu di asal engkau jadi upas asal engkau, jadi upas orang beranak muda, asal engkau jadi air liur, asal engkau jadi kebal, berkata laa ilaaha illallah.

\section{Sakit perut}

Inilah do'a atau tawa sakik perut dan rabusannyo. Bismillahirrahmanirrahim: talam ta ilallazi na kharaju min diya rihim uluf hazal ral mauti, faqali lahu mullahu mutu. Sudah tu, katanya: hai kacang-kacang rayu si anu (nama orangnya) janganlah engkau merusakkan, maniayo pado si anu. Kalau engkau marusakkan, maniayo si anu (nama orang yang diobati). Engkau disumpahi Allah, disumpahi Muhammad, disumpahi Quran tigo puluah juz. Qabul berkat laa ilaha illa allah Muhammad Rasulullah. Ramuannyo yakni: kalau mamiyuahmiyuah, mancucuak-cucuak, mamilin-milin: urek salayo, sakajadu rendam jo air panas manggalagak, alah dingin minum. Kalu mangareok: ramuannyo daun kuciang jo supadan. Tokok randam jo air hangek. Minum. Sampahnyo lampokkan ka paruik.

Inilah do'a atau tawa sakit perut dan rebusannya. Bismillahirrahmanirrahim: talam ta ilallazi na kharaju min diya rihim ulufhazal ral mauti, faqali lahu mullahu mutu. Sesudah tu, katanya: hai kacang-kacang rayu si anu (nama orangnya) janganlah engkau merusakkan, mainanyo pado si anu. Kalau engku marusakkan, menganiaya si anu (nama orang yang diobati). Engkau disumpahi Allah, disumpahi Muhammad, disumpahi Quran tigo puluah juz. Qabul berkat laa ilaha illa allah Muhammad Rasulullah. Ramuannya yakni: kalau perih, mancucuk-cucuk, memilin-milin: akar selaya, sakajadu rendam dengan air panas mendidih, sesudah dingin minum. Kalau mangareok: ramuannya daun kucing dengan supadan. Tokok rendam dengan air hangat diminum. Ampasnya tempelkan ke perut.

\section{Pengobatan dengan menggunakan azimat}

Penggunaan azimat sebagai pengobatan yang ditemukan dalam naskahnaskah penelitian sangat beragam, dari penyakit tubuh manusia maupun lingkungan alam (rumah, padi, lapau dan lain-lain). Penting dikemukakan di sini bahwa suatu azimat untuk tujuan pengobatan penyakit tertentu ditemukan sama bentuknya dalam bebefrapa naskah yang memuatnya. Artinya, ada standar atau acuan yang sama untuk pembuatan azimat. Adapun perbedaan yang muncul hanya pada jenis tulisan dan kehalusan penyalinnya.

Praktik pengobatan dengan menggunakan azimat sampai sekarang masih banyak dipraktikkan oleh masyarakat tradisional Minangkabau. Banyak surausurau tarekat yang para syekhnya masih diminati untuk membuat azimat. Dengan demikian, pengobatan jenis ini juga penting untuk dijelaskan konteks budayanya. 
Danang Susena, dkk.

Berikut ini akan disajikan gambar-gambar naskah yang memuat azimat pengobatan.

Gambar 1. Azimat tangkal burung

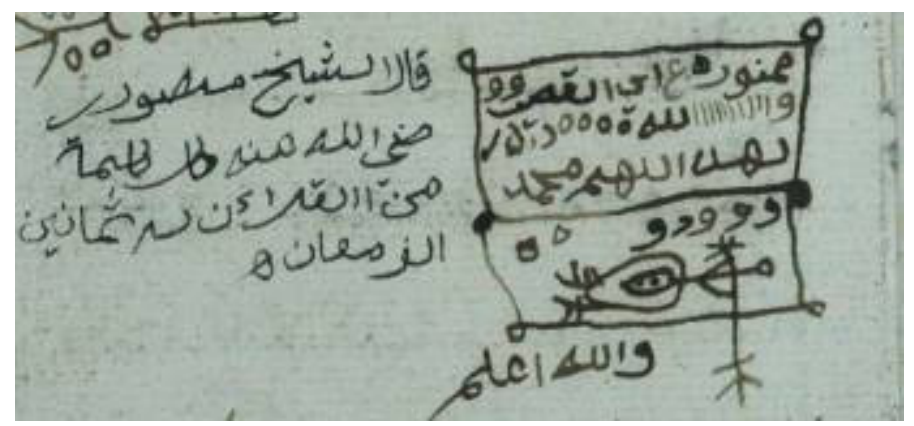

Gambar 2. Azimat tangkal tikus, ulat, tupai

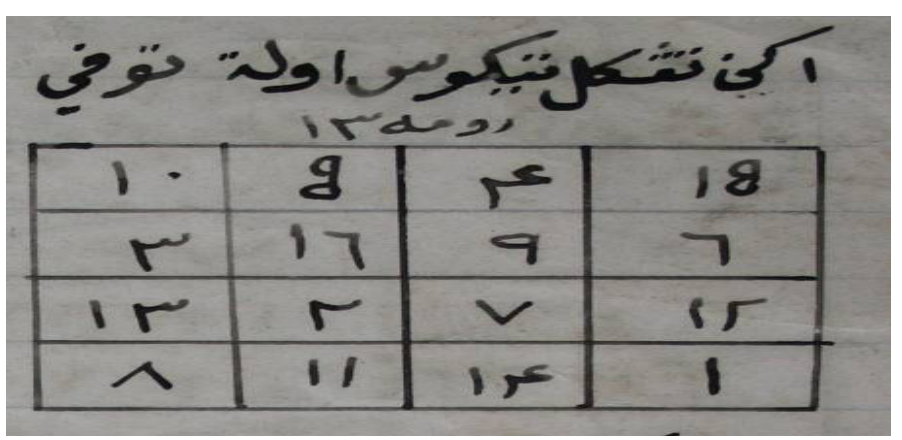

Gambar 3. Azimat tangkal penyakit parah

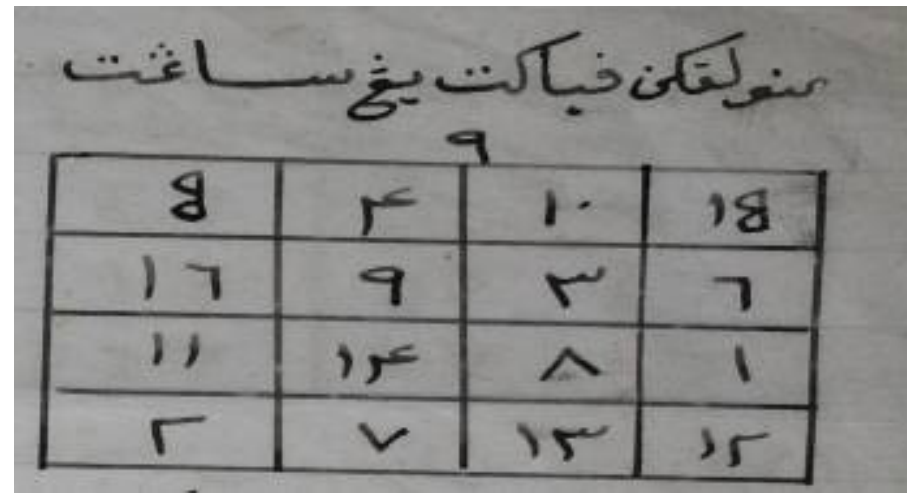

Gambar 4. Azimat untuk memperlancar perempuan yang susah melahirkan

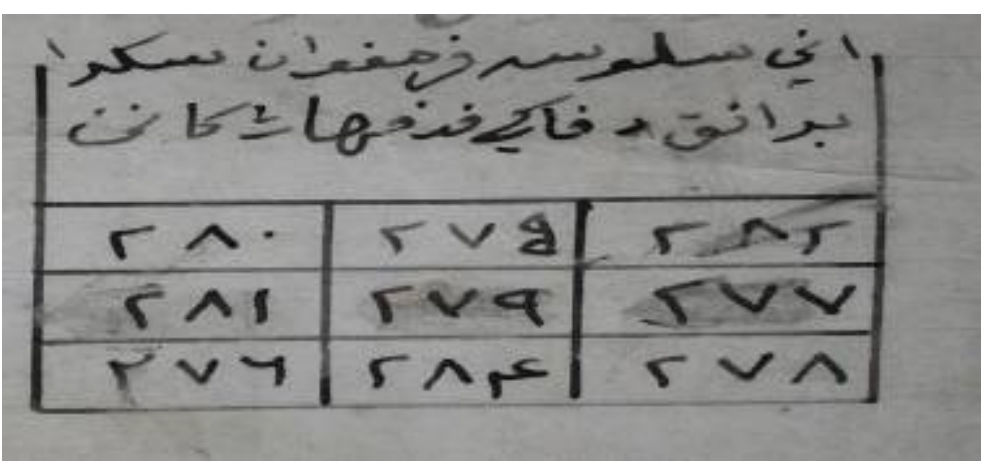




\section{Konteks Budaya Pengobatan Tradisional Minangkabau dalam Perspektif Etnomedisin}

Dalam perspektif etnomedisin, penyebab seseorang menjadi sakit dapat disebabkan oleh faktor personalistik (makhluk halus) dan faktor naturalistik (fisikal). Sakit atau penyakit yang disebabkan oleh faktor personalistik akan berbeda pengobatannya dengan yang disebabkan oleh faktor naturalistik. Jika yang pertama diobati dengan kekuatan gaib (mantra, doa atau gabunagan mantra dan ramuan), maka yang kedua pengobatannya akan menggunakan ramuan dari bahan-bahan tumbuhan (herbalmedicine) dan hewan (animalmedicine) atau gabungan keduanya. (Foster dan Anderson, 1986:63-64).

Dengan pendekatan etnomedisin juga, peneliti akan terbantu untujk mengetahui sifat dari sistem-sistem pengobatan (kesehatan) tradisional Minangkabau dan khususnya konsep-konsep tentang sebab-akibat penyakit yang mendasarinya. Secara lebih jauh, melalui pendekatan ini akan dapat memaknai aspek kosmologi masyarakat Minangkabau tradisional yang berkaitan dengan sakit dan pengobatannya. Salah satu ontologis yang dapat dimaknai untuk mesjelaskan aspek kosmologi tersebut adalah melalui teks pengobatan tradisional yang terkandung dalam naskah-naskah penelitian.

Dalam masyarakat tradisonal di Indoensia, pengetahuan lokal terkait pengobatan tradisional kebanyakan terekam dalam ingatan lisan masyarakatnya. Dalam konteks ini, salah satunya pernah dikumpulkan dan dikaji oleh Limananti dan Atik Triratnawati (2002). Kajiannya menghasilkan tentang ramuan penambah nafsu makan pengaruh faktor kepercayaan atau sugesti akan khasiat jamu cekok. Namun demikian, pengetahuan masyarakat lokal tentang pengobatan tradisional juga tersedia atau terekam dalam bentuk tertulis, yakni dalam naskah-naskah kuno seperti dalam naskah-naskah penelitian yang diteliti ini. Kajian terhadap rekaman tertulis tentang pengetahuan pengobatan tradisional di antaranya seperti yang dilakukan oleh Nawangningrum, dkk (2004) dan Andri (2012).

Teks pengobatan tradisional yang ditemukan dalam naskah-naskah Minangkabau, memiliki karakteristik yang unik. Keunikannya tampak pada banyaknya ditemukan mantra, doa dan azimat yang digunakan untuk pengobatan.

Selain itu, teks pengobatan tidak hanya untuk pengobatan tubuh yang sakit saja, tetapi pengobatan lingkungan (bagian di luar tubuh manusia) yang sakit juga ada. Hal ini, misalnya banyak ditemukan teks-teks pengobatan tradisional untuk paureh (obat) rumah, paureh lapau, padi dan paureh ternak. Teks-teks pengobatan seperti ini kehadirannya selalu dalam uraian teks pengobatan untuk obat demam, obat sakit perut dan obat-obat yang lain untuk penyakit tubuh (fisik) manusia.

Dapat dimaknai bahwa masyarakat Minangkabau secara tradisional memiliki konsep tentang sehat dan sakit yang bermuara pada "raso", rasa. Jika apa yang diinginkan tidak sesuai dengan kenyataan akan menimbulkan "rasa sakit". Badan dirasa tidak segar, perut terasa tidak enak, rumah terasa tidak nyaman, lapau yang tidak kunjung mendatangkan untung, semuanya merupakan kondisi yang menyebabkan "rasa" sakit. Oleh karena itu, "rasa" sakit itu harus dicarikan 
obatnya agar "apa yang diinginkan menjadi kenyataan".

Pada masyarakat Minangkabau tradisional sakit adakalanya dipercaya disebabkan oleh makhluk gaib (jin, setan, dan lainnya). Dengan demikian, pengobatannya dilakukan dengan cara memantrai ramuan obat yang diberikan kepada orang yang sakit dengan bantuan 'orang pintar' atau dukun. Praktik memberi mantra pada ramuan ini disebut dengan tawa.

Penyakit yang disebabkan oleh faktor personalistik maupun naturalistik dan pengobatannya ditemukan dalam naskah-naskah Minangkabau yang mengandung teks pengobatan tradisional. Pengobatan secara tradisional tersebut masih dipraktikkan dalam kehidupan masyarakat Minangkabau secara tradisional.

Dalam konteks pengertian yang terakhir, dalam kebudayaan Minangkabau dikenal sebuah ungkapan berikut: manto istilah dukun, doa bahaso urang siak 'mantra istilah dukun, doa bahasa alim ulama'. Akan tetapi, pada kenyataannya antara mantra dan doa juga terkadang digunakan secara bersamaan. Praktik pengobatan yang dilakukan seorang syekh masih banyak ditemui di tengah-tengah masyarakat Minangkabau tradisional. Salah satu contoh praktik tersebut dapat dilihat pada gambar 1.

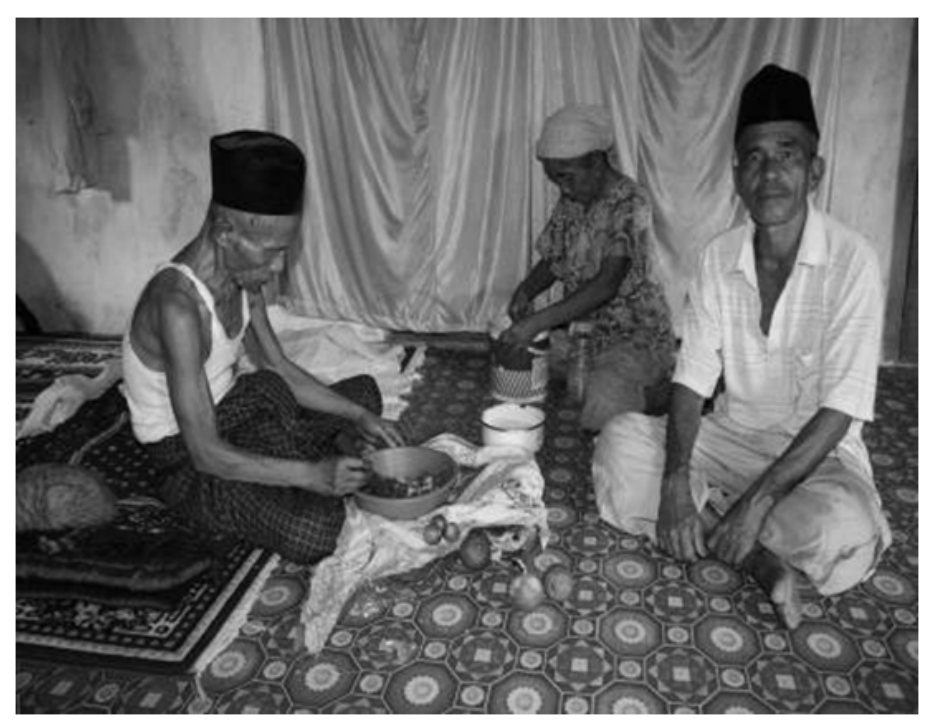

Gambar 5. Abdul Muas Gelar Tantua Rajo Sutan (w. 2009) sedang memantrai ramuan yang diminta oleh Masrul (55 tahun) untuk obat anaknya yang sedang menderita demam tinggi

Dalam praktiknya, pengobatan yang dilakukan oleh seorang buya dan atau syekh menggunakan sistem pengobatan dengan ramuan saja, pengobatan dengan mantra dan atau doa saja, pengobatan dengan ramuan dan mantra dan pengobatan dengan menggunakan azimat. Penggunaan masing-masing sistem pengobatan tersebut disesuaikan dengan jenis penyakit yang dikeluhkan oleh orang yang datang. Hal ini sekaligus membuktikan bahwa peran buya dan atau syekh tarekat tidak hanya pada persoalan keagamaan saja, tetapi juga pada persoalan medis. 


\section{Simpulan}

Teks pengobatan tradisional yang terkandung di dalam naskah-naskah Minangkabau merupakan khasanah budaya yang penting baik secara akademis maupun sosial budaya. Secara akademis melalui teks-teks itu dapat diungkap nilai-nilai yang relevan dengan kehidupan sekarang. Secara sosial budaya, naskahnaskah yang mengandung teks mantra itu merupakan identitas, kebanggaan dan warisan yang berharga. Ia merupakan hasil kegiatan intelektual dalam masyarakat tradisional (local genius).

Teks pengobatan tradisional yang ditemukan dari naskah penelitian yang berjumlah 27 naskah Minangkabau, dapat dikelompokkan menjadi empat jenis pengobatan tradisional Minangkabau, yakni pengobatan dengan ramuan saja, pengobatan dengan mantra dan atau doa saja, pengobatan dengan ramuan dan mantra dan pengobatan dengan menggunakan azimat. Berbeda dengan jenis pengobatan ketiga dan keempat, jenis pengobatan yang pertama sangat sedikit ditemukan di dalam naskah-naskah penelitian.

Dalam perspektif etnomedisin, dengan banyak ditemukannyajenis pengobatan yang menggunakan mantra dan azimat dapat dimaknai bahwa dalam kosmologi masyarakat tradisional Minangkabau memaknai sakit lebih banyak yang disebabkan oleh faktor personalistik. Oleh karena itu, pengobatan untuk penyakitnya, selain menggunakan ramuan obat juga harus menggunakan kekuatan gaib.

\section{DAFTAR PUSTAKA}

Afiani Ika Limananti, Atik Triratnawati. 2003. "Ramuan Jamu Cekok Sebagai Penyembuhan Kurang Nafsu Makan Pada Anak: Suatu Kajian Etnomedisin". Artikel dalam Jurnal MAKARA, KESEHATAN, VOL. 7, NO. 1, JUNI 2003.

Akhimuddin, Yusri, Andriana Yohan \& Fitria Dewi. 2009. "Penelusuran dan Deskripsi Naskah-naskah Koleksi Pribadi di Kabupaten Dharmasraya". Laporan Penelitian. Padang : Balai Bahasa Padang.

Akhimuddin, Yusri. 2007. "Pemetaan Naskah-naskah Keagamaan di Padang Pariaman". Laporan Penelitian. Batusangkar : STAIN Batusangkar.

Andri, Wirma. 2012. "Pengobatan Tradisional dalam Naskah Kuno Koleksi Surau Tarekat Syattariyah di Pariangan: Transliterasi dan Analisis Etnomedisin". Skripsi. Padang: Fakultas Ilmu Budaya Universitas Andalas.

Foster, George M dan Anderson. 1986. Antropologi Kesehatan. Terjemahan. Jakarta: UI Press.

Katkova, Irina \& Pramono. 2009. “Endangered Manuscripts of Western Sumatra: Collections of Sufi Brotherhoods". (Laporan Penelitian pada Programme Endangered, British Library, London).

Katkova, Irina \& Pramono. 2011. "Endangered manuscripts of Western Sumatra and the province of Jambi. Collections of Sufi brotherhoods". (Laporan Penelitian pada Programme Endangered, British Library, London).

Miles, Matthew dan A. Michael Huberman. 1992. Analisis Data Kualitatif. Terjemahan. Jakarta: UI Press.

Nawangningrum, Dina, dkk. 2004. "Kajian Terhadap Naskah Kuna Nusantara Koleksi Fakultas Ilmu Pengetahuan Budaya Universitas Indonesia: Penyakit Dan Pengobatan Ramuan Tradisional". Artikel dalam Jurnal MAKARA Sosial Humaniora, Vol. 8, NO. 2, Agustus 2004: 45-53. 
Pramono. 2009. “Inventarisasi, Katalogisasi dan Digitalisasi Naskah-naskah Kuno Melayu dan Upaya Penyelamatannya di Sumatera Barat, Riau dan Kepulauan Riau. Laporan Penelitian. Padang : Lembaga Penelitian Universitas Andalas.

Usman, Fajri. 2005. "Metafora dalam Mantra Minangkabau”. Tesis. Denpasar : Program Pascasarjana Universitas Udayana.

Yusuf, M. (Penyunting). 2006. Katalogus Manuskrip dan Skriptorium Minangkabau. Tokyo : Centre for Documentation and Area-Transcultural Studies, Tokyo University of Foreign Studies.

Yusuf, M., Andriana Yohan \& Fitria Dewi. 2008. "Penelusuran Naskah di Kota Sawahlunto dan Kabupaten Sijunjung", Laporan Penelitian. Padang : Balai Bahasa Padang.

Zuriati. 2003. Undang-Undang Minangkabau, Pengaruh Tasawuf dan Dinamika Hukum Adat di Bawah Pengaruh Hukum Islam (Syarak), (Suntingan Teks dan Analisis Isi). Tesis pada Program Pascasarjana Ilmu Pengetahuan Budaya Universitas Indonesia). Jakarta : Fakultas Ilmu Pengetahuan Budaya UI.

Zuriati. 2008. "The Digitisation of Minangkabau's Manuscript Collections in Suraus". (Laporan Penelitian pada Programme Endangered, British Library, London). 